\title{
Numerical Study on the Thickness of the Window Spill Plume in External Façade Fire
}

\author{
Jiajia Fu ${ }^{1, a}$, Jianguo Chen ${ }^{1, b}$ and Hongyong Yuan ${ }^{1, c}$ \\ ${ }^{1}$ Department of Engineering Physics, Institute of Public Safety Research, Tsinghua University \\ No.1, Qinghua Garden, Haidian District, Beijing, China \\ afujj0113@163.com, ${ }^{b}$ chenjianguo@mail.tsinghua.edu.cn, cyuanhongyong@mail.tsinghua.edu.cn
}

Keywords: window spill plume, external façade fire, under-ventilated fire, flame thickness.

Abstract. It is believed that the ventilation factor plays an important role to define the thickness of the window spill plume. However, the effect of the window height/width ratio on the spill plume thickness couldn't been concerned in previous research. To obtain more influencing factors of the window spill plume thickness, a series of numerical simulation and theoretical analysis have been done in this paper. And the correlation of the window spill thickness is proposed by introducing the window height/width ratio $\lambda$ and the length scale $l_{2}$, which is of great significance of fire protection of the building fire.

\section{Introduction}

With the rapid development of our country's economy and people's living standards, the number of building fire accidents and the severity of fire have shown an upward trend. The rapid spread of flame on the building façade is a typical feature of a building fire. The phenomenon of the window spill plume has gradually attracted the attention of scholars at home and abroad which caused by insufficient ventilation indoor room.

Characterizing the size of the window has two factors: the ventilation factor $\left(l_{1}=\left(\mathrm{AH}^{1 / 2}\right)^{2 / 5}\right)$ and the window height/width ratio $(\lambda=\mathrm{H} / \mathrm{W})$. Yokoi [1] had demonstrated by using models, the window width/height ratio had an important effect on the flame trajectory. With wide windows the flame does not project far from the façade but clings to the wall above but with narrow windows it tends not to. And when the flame front is narrow, it is easier for cold air to enter the fire room between the façade and the flames. However, the dimensionless equation of the window spill plume proposed by previous scholars only considers the influence of ventilation factors, does not consider the influence of the window height/width radio, such as the dimensionless temperature distribution equation, flame height equation, and flame thickness equation based on ventilation factor by Lee Yee-Ping [2,3,4]. It is the purpose of this paper to numerical study the thickness of window spill plume by considering the ventilation factor and the window height/width ratio. Obtaining the accurate thickness of window spill plume is very important for studying the trajectory of window spill plume under limit of the horizontal barrier above the window.

This paper bases on 1:2 reduced-scale test bench we have built using FDS software, which consistent with pre-built test rig size [5]. A series of models for different sizes of window and heat release rate are simulated. Based on the previous research results, the factor of the window height/width ratio $\lambda$ is introduced here to establish the model of the thickness of window spill plume from the indoor fire.

\section{Physical model settings}

The geometry of test bench consisted of 6 rooms. The total size of test bench is $4.78 \mathrm{~m}$ wide $\times 3.78 \mathrm{~m}$ deep $\times 4.5 \mathrm{~m}$ high, and the inside size of each room is $3.3 \mathrm{~m}$ wide $\times 2 \mathrm{~m}$ deep $\times 1.3 \mathrm{~m}$ high. Ventilation was provided by the window opening only. Outline of model configuration and the location of thermocouples are shown in Fig. 1. 


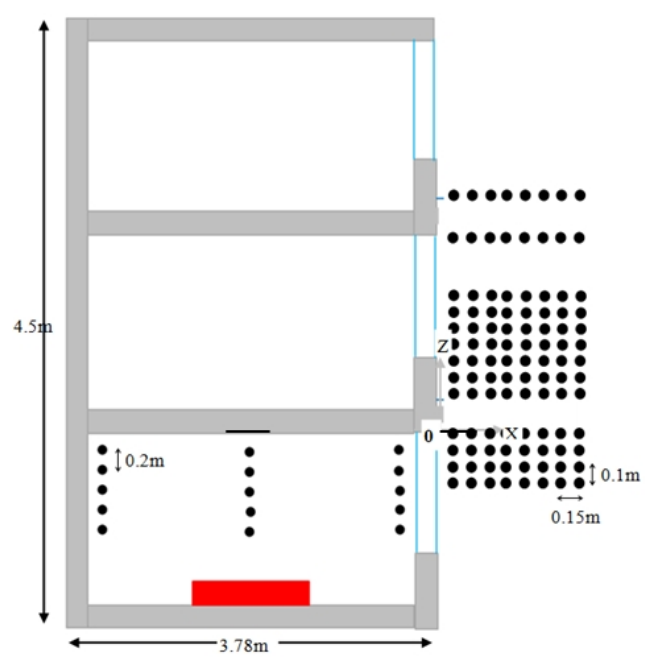

(a) side view

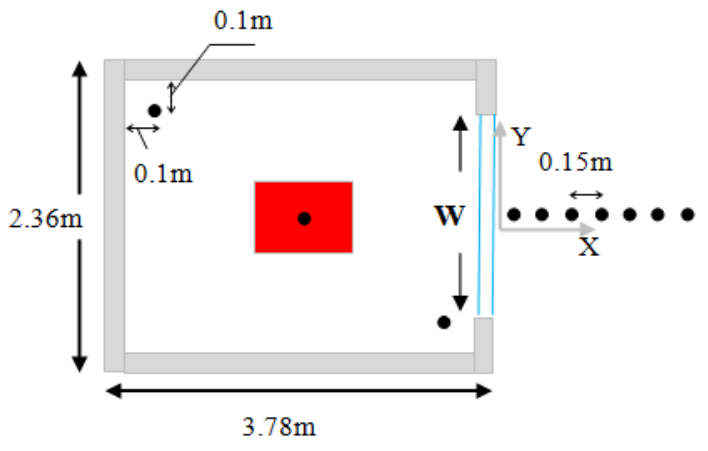

(b) top view

Fig. 1. Outline of model configuration

The following assumptions are used in the simulation:

(1) The paper has designed a series of simulation experimental schemes, including 5 kinds of window sizes and 4 kinds of fire powers, to study the temperature distribution outside the building façade. As shown in table 1.

(2) The fire source is in the middle of the first-floor room in the combustion chamber with the size of $1 \mathrm{~m} \times 1 \mathrm{~m}$.

(3) The wall is made of $20 \mathrm{~cm}$ thick firebrick, the density is $750.0 \mathrm{~kg} / \mathrm{m} 3$, the specific heat is $1.04 \mathrm{~kJ} /(\mathrm{kg} \cdot \mathrm{K})$ and the thermal conductivity is $0.38 \mathrm{~W} /(\mathrm{m} \cdot \mathrm{k})$.

(4) The ambient temperature is $18^{\circ} \mathrm{C}$, without considering the influence of outside wind.

(5) The type of fire growth is described by the $t^{2}$ model that commonly used in the fire engineering. The fire growth factor $(\alpha=0.0469)$ is taken as fast fire.

Table 1. Simulation Experimental Schemes

\begin{tabular}{ccc}
\hline \multicolumn{2}{c}{ Window Size } & \multicolumn{2}{c}{ Fire Power ( kW ) } \\
\cline { 1 - 2 } Width $(\mathbf{~ m ~ ) ~}$ & Height $(\mathbf{~ m ~ )}$ & $1000 \mathrm{~kW} 、 1500 \mathrm{~kW} 、 2000 \mathrm{~kW} 、 3000 \mathrm{~kW}$ \\
\hline 0.8 & 0.5 & $1000 \mathrm{~kW} 、 1500 \mathrm{~kW} 、 2000 \mathrm{~kW} 、 3000 \mathrm{~kW}$ \\
\hline 0.8 & 0.8 & $1000 \mathrm{~kW} 、 1500 \mathrm{~kW} 、 2000 \mathrm{~kW} 、 3000 \mathrm{~kW}$ \\
\hline 1 & 0.8 & $1000 \mathrm{~kW} 、 1500 \mathrm{~kW} 、 2000 \mathrm{~kW} 、 3000 \mathrm{~kW}$ \\
\hline 0.9 & 0.9 & $1000 \mathrm{~kW} 、 1500 \mathrm{~kW} 、 2000 \mathrm{~kW} 、 3000 \mathrm{~kW}$ \\
\hline 1.3 & 1 &
\end{tabular}

In the FDS simulation, it is necessary to evaluate the grid independently to ensure that the simulation results do not depend on the size of the grid scale. After the comparing simulation for the four grid scales $(0.025 \mathrm{~m}, 0.05 \mathrm{~m}, 0.1 \mathrm{~m}$, and $0.15 \mathrm{~m})$, we found that the simulation result is best on the computational accuracy and computation time when the grid size is $0.05 \mathrm{~m}$.

\section{Results and discussion}

At present, there are two methods to define the flame tip that are most commonly used, based on visual and measured temperature. The temperature-based definition method uses a flame tip of $500^{\circ} \mathrm{C}$ as a criterion for the flame profile [6-7]. Therefore, we also choose $500^{\circ} \mathrm{C}$ as a criterion to define the flame tip in this paper.

Fig. 2 and Fig. 3 are the isothermal diagram of the window spill plume under different fire release rate when the window size is $0.8 \mathrm{~m} \times 0.5 \mathrm{~m}$ and $0.9 \mathrm{~m} \times 0.9 \mathrm{~m}$ respectively. By analyzing the isothermal plots of the window spill plume under free boundary conditions for each window size, the 
following conditions can be drawn: 1) The window spill plume thickness and window spill plume height increase with the increase of the total heat release rate, but the growth rate slows down, when the window size is constant. 2) The thickness of the window spill plume increases with the increase of the vertical height first, and then decrease after the maximum of the thickness $\left(D_{\text {fmax }}\right)$. Because of the horizontal momentum, the window spill plume moves a horizontal distance from the top of the window. When the buoyancy of the window spill plume and its horizontal momentum compete with each other to reach the balance, the thickness of the window spill plume reaches the maximum. Then the window spill plume is mainly affected by the buoyancy, and the window spill plum gradually decrease due to the air entrainment.
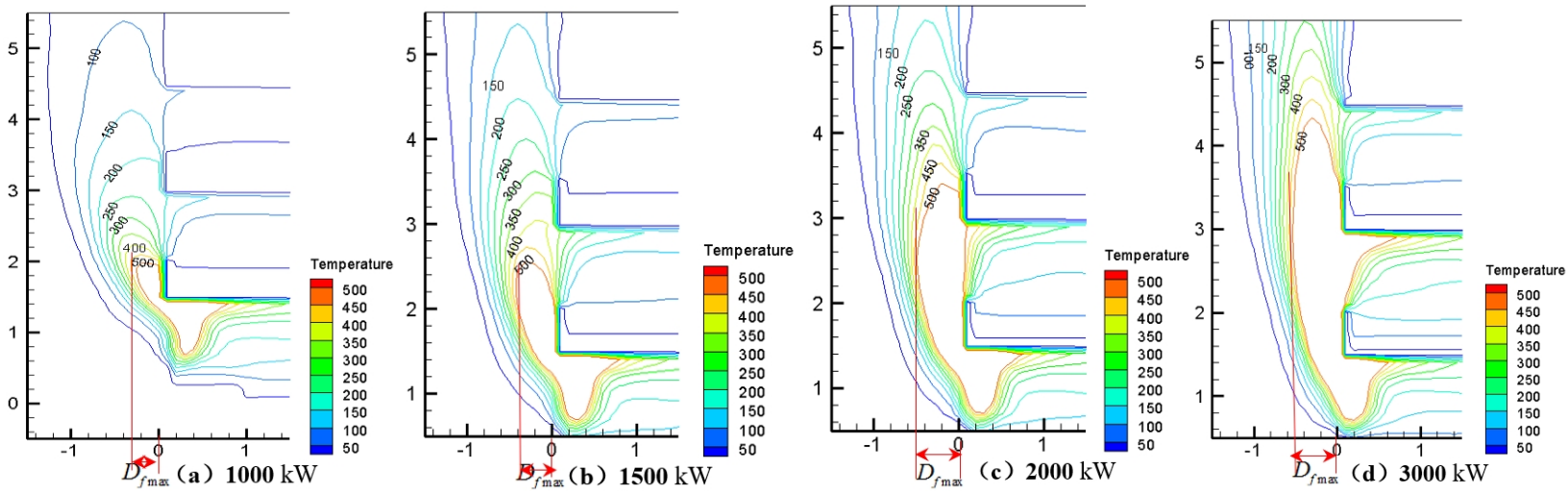

Fig.2. The isothermal diagram of the window spill plume when the window size is $0.8 \mathrm{~m} \times 0.5 \mathrm{~m}$
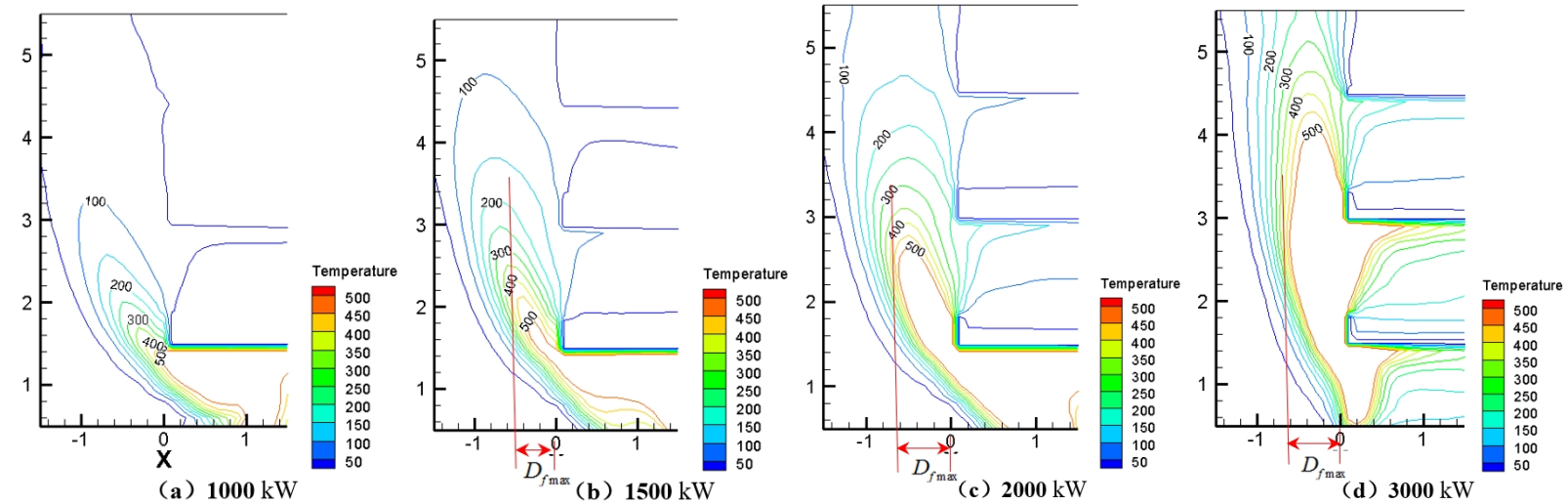

Fig.3. The isothermal diagram of the window spill plume when the window size is $0.9 \mathrm{~m} \times 0.9 \mathrm{~m}$.

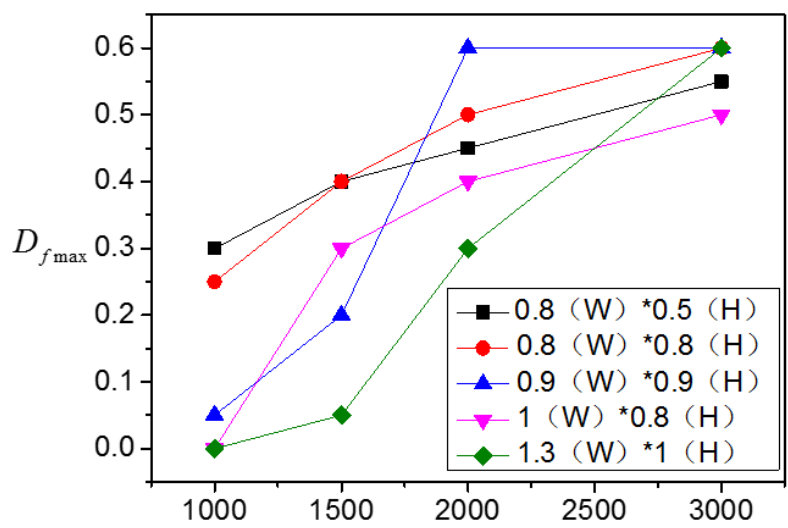

$Q$

Fig.4. The variation of the maximum thickness of window spill plume

From the Fig.4., we can see the thickness of the window spill plume is approximately 0 when the window size is $0.9 \mathrm{~m} \times 0.9 \mathrm{~m}, 0.9 \mathrm{~m} \times 0.9 \mathrm{~m}$ and $1.3 \mathrm{~m} \times 1 \mathrm{~m}$ in the fire power is $1000 \mathrm{~kW}$. The main reason is that the combustion in the room is very full and the size of the interior flame is controlled by the amount of fuel so that there is almost no unflammable gas leaking from window. However, when the window size is $0.8 \mathrm{~m} \times 0.5 \mathrm{~m}$ and $0.8 \mathrm{~m} \times 0.8 \mathrm{~m}$, the thickness of the window spill plume increases with the increase of the fire power, but the growth rate decreases. 
Zengwei Qiu et al. [8] proposed an equation for the window spill plume thickness based on the previous researches and the length scale $l_{2}$.

$$
\frac{D_{\text {fmax }}}{Z_{\mathrm{f}}}=0.43 \frac{1_{2}}{Z_{\mathrm{f}}}+0.02
$$

Where the length scale $\mathrm{l}_{2}=\left(\mathrm{AH}^{2}\right)^{1 / 4}, \mathrm{Z}_{\mathrm{f}}$ is the measured spill plume height taking $500^{\circ} \mathrm{C}$ as the locus of the flame tip.

From the previous researches, the spill plume height will be general determined by the length scale $l_{1}=\left(\mathrm{AH}^{1 / 2}\right)^{2 / 5}$ and the dimensionless overflow heat release rate $\mathrm{Q}^{*}{ }_{\mathrm{ex}}=\mathrm{Q}^{*}-1500 \mathrm{~A} \sqrt{\mathrm{H}}$. $[3,4]$ :

$$
\frac{Z_{\mathrm{f}}}{1_{1}}=\operatorname{fcn}\left(Q_{\mathrm{ex}}^{*}\right)=\operatorname{fcn}\left(\frac{\mathrm{Q}_{\mathrm{ex}}^{*}}{\rho_{\infty} \mathrm{C}_{\mathrm{p}} \mathrm{T}_{\infty} \sqrt{\mathrm{g}} 1_{1}^{2 / 5}}\right)
$$

In this expression, the fitting index is $2 / 3$ when $\mathrm{Q}^{*}{ }_{\mathrm{ex}}<1.3$, which is consistent with the two-dimensional linear fire source. But when the overflow heat release rate is larger than 1.3 $\left(\mathrm{Q}^{*}{ }_{\mathrm{ex}}>1.3\right)$, the fitting index is $2 / 5$, and the spill plume height model approximates the axisymmetric flame height model.

Eq. (1) then becomes :

$$
\mathrm{D}_{\mathrm{fmax}}=\mathrm{fcn}\left(\mathrm{Q}_{\mathrm{ex}}^{*}, 1_{1}, 1_{2}\right)
$$

Moreover, the length scales $l_{1}=\left(\mathrm{AH}^{1 / 2}\right)^{2 / 5}$ and $l_{2}=\left(\mathrm{AH}^{2}\right)^{1 / 4}$ all have some relation with the window width $\mathrm{W}$ and the window height $\mathrm{H}$.

$$
\frac{\mathrm{l}_{2}}{\mathrm{l}_{1}}=\left(\frac{\mathrm{H}}{\mathrm{W}}\right)^{3 / 20}=\lambda^{3 / 20}
$$

For the under-ventilated combustion, the dimensionless overflow heat release rate $\mathrm{Q}^{*}{ }_{\mathrm{ex}, \mathrm{D}}$ of coupling the window height/width ratio $\lambda$ can be defined as [5]:

$$
\mathrm{Q}_{\mathrm{ex}, \mathrm{D}}^{*}=\frac{\mathrm{Q}_{\mathrm{ex}}^{*}}{\rho_{\infty} \mathrm{C}_{\mathrm{p}} \mathrm{T}_{\infty} \sqrt{\mathrm{g}} \lambda^{3 / 8} 1_{1}^{7 / 2}}
$$

Therefore the Eq. (3) for the window spill plume thickness is recalled:

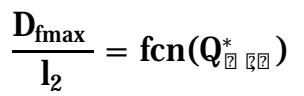

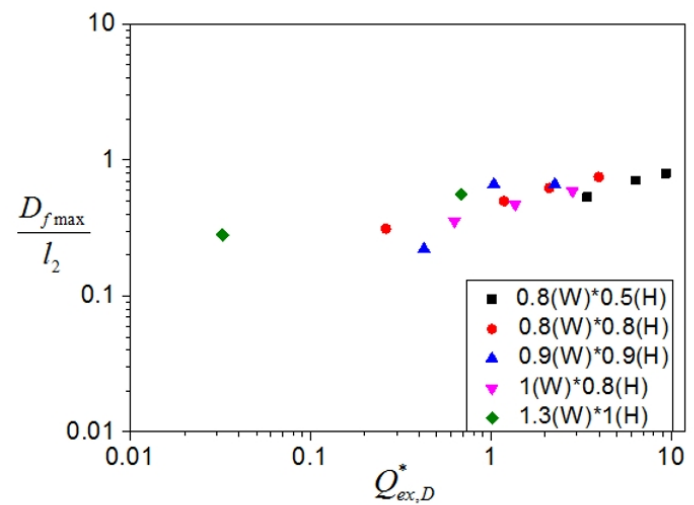

(a)

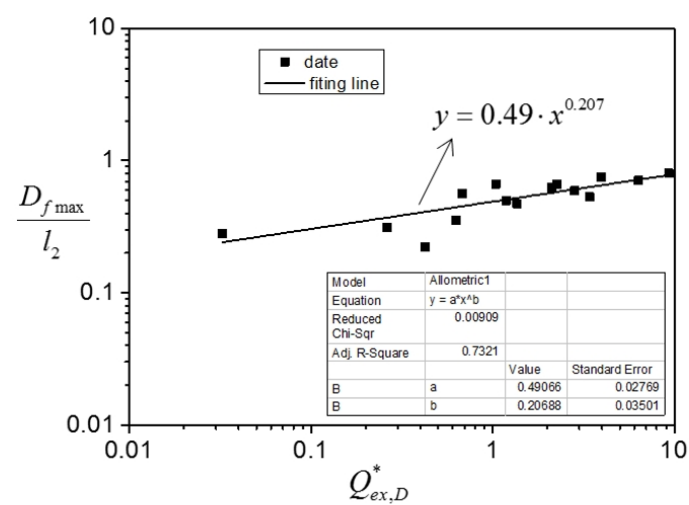

(b)

Fig 5 The window spill plume thickness correlation using Eq.(6) for all experiments.

Fig.5a demonstrates that for under-ventilated fire the window spill plume thickness dependence on the length scale $l_{2}$ and the dimensionless overflow heat release rate $\mathrm{Q}^{*}{ }_{\text {ex,D. }}$. The correlation of the 
window spill plume thickness is shown in Fig. 5b. The thickness of the window spill plume is redefined as:

$$
\frac{\mathrm{D}_{\mathrm{fmax}}}{\mathrm{l}_{2}}=0.49 *\left(\mathrm{Q}_{\mathrm{ex}, \mathrm{D}}^{*}\right)^{0.207}
$$

\section{Conclusions}

The analysis in this work reveals new insights for the safety engineering for flames on façade as the plume spill from the indoor fire. The main contributions are:

(1) When the ventilation factor is constant, the thickness of the window spill plume increases with the increase of the total heat release rate, but the growth rate slows down. The thickness of the window spill plume increases with the increase of the vertical height first, and then decrease after the maximum of the thickness $\left(\mathrm{D}_{\mathrm{fmax}}\right)$.

(2) For the under-ventilated combustion, the variation of maximum the thickness of the window spill plume can be well characterized by using the the length scale $l_{2}$ and the window height/width ratio $\lambda$. A mathematical model for the maximum thickness of the window spill plume under free boundary conditions is proposed as Eq. (7).

\section{Acknowledgements}

This work was financially supported by the National Natural Science Foundation of China (Grant No. 71790613).

\section{References}

[1] Yokio S., in: Study on the prevention of fire-spread caused by not upward current. Edited by Building Research Institute Report No 34, Tokyo (1960).

[2] Lee Y P., in: Heat fluxes and flame heights in external facade fires. PhD Thesis of University of Ulster (2006).

[3] Lee Y P, Delichatsios M A, Ohmiya Y, Wakatsuki K, Yanagisawa A, Goto D, in: Heat fluxes on opposite building wall by flames emerging from an enclosure. Volume 32 of Proceedings of the Combustion Institute, (2009), p. 2551-2558.

[4] Delichatsios M A, Lee Y P, Tofilo P., in: A new correlation for gas temperature inside a burning enclosure, volume 44 of Fire Safety Journal, chapter 8 (2009), p. 1003-1009.

[5] Jiajia Fu, Yinqing Li, Jiangyan Zhang, in: Influence of window size on the window spill plume. Volume 35 of Fire Science and Technology Journal, chapter 3 (2016), p. 316-320.

[6] Thomas, P.H. and Law, M, in: The Projection of Flames from Buildings on Fire, volume 10 of Fire Prevention Science Technology, (1997), p.19-26.

[7] Chamchine AV, Graham TL, Makhviladze GM, Holmstedt G, Snegireu AY, Talalov VA, in: Experimental studies of under-ventilated combustion in small and medium-scale enclosures. Proceedings of the fourth international seminar on fire and explosion hazards, (2003), p. 97-100.

[8] Zengwei Qiu, Studies on evolution and model of flame width and depth of ejected flame form ventilation control enclose fire. Master's thesis of University of Science and Technology of China, (2015). 